DOI: https://doi.org/10.32839/2304-5809/2021-7-95-10

УДК 37.022

Черняк С.Г.

Київська муніципальна академія естрадного та циркового мистецтв

\title{
ПЕРСОНІФІКОВАНИЙ ПІДХІД ДО ВИВЧЕННЯ ПРОБЛЕМИ ОСВІТНЬО-ПЕДАГОГІЧНОГО ПРОГНОЗУВАННЯ В УКРАЇНІ (1917-1920 РР.)
}

\begin{abstract}
Анотація. У статті проаналізовано персонірікований підхід до вивчення проблеми освітньо-педагогічного прогнозування в Україні періоду 1917-1920рр. Автором представлено просвітницько-педагогічну та громадсько-політичну діяльність М.С. Грушевського, феномен якого детермінуеться низкою об'єктивних i суб'єктивних причин. Учений наголошуе, що з іменем М.С. Грушевського пов'язані зародження, а відтак інституціоналізація української історіографії як допоміжної дисципліни тоді, і спеціальної галузі історичної науки - сьогодні, роль та значення якої дедалі підвищуеться у сучасних умовах. Дослідник розкривае вагомий з точки зору освітньо-прогнозувального потенціалу доробок всесвітньовідомого вченого-натураліста, педагога і просвітителя В.I. Вернадського, який через розкриття своєї сутності у різні періоди життя всебічно проаналізував вузлові питання педагогічної антропології, переконливо висвітлив дію закону апперцепщії. Педагог стверджуе, що одним із найважливіших завдань освітньо-педагогічного прогнозування е оцінка моделі національно-державного будівництва П.П. Скоропадського, яка зароджувалася і викристалізовувалася у процесі збройної боротьби за самостійну українську державу. Освітянин висвітлюе внесок видатного письменника, публіциста, суспільно-політичного діяча В.К. Винниченка у теорію та практику освітньо-педагогічного прогнозування.
\end{abstract}

Ключові слова: персоніфікація, персоніфікований підхід, проблеми освітньо-педагогічного прогнозування, національно-визвольна боротьба, освітні реформи.

Cherniak Sergii

Kyiv Municipal Academy of Circus and Preforming Arts

\section{PERSONALIZED APPROACH TO STUDYING THE PROBLEM OF EDUCATIONAL AND PEDAGOGICAL FORECASTING IN UKRAINE (1917-1920)}

Summary. The article covers a personalized approach to studying the problem of educational and pedagogical forecasting in Ukraine in the period 1917-1920. The author analyzes four personalities and concludes that the stated problem of the period of national liberation struggles is marked by a tendency to multilevel pedagogical training, namely: M.S. Hrushevsky made efforts to form a national university education, cared about expanding the block of Ukrainian studies disciplines. The scientist emphasizes that with the name of M.S. Hrushevsky's origins are connected, and thus the institutionalization of Ukrainian historiography as an auxiliary discipline then, and a special branch of historical science - today, the role and importance of which is increasingly increasing in modern conditions. V.I. Vernadsky developed the concept of the Ukrainian Academy of Sciences, raised the issue of compulsory education in primary schools and free higher and technical education, stressed the importance of family and social environment as factors in the ability of self-realization of the human person. The researcher reveals a significant from the point of view of educational and predictive potential achievements of the world-famous scientist-naturalist, teacher and educator V.I. Vernadsky, who through the disclosure of its essence in different periods of life comprehensively analyzed the key issues of pedagogical anthropology, convincingly highlighted the effect of the law of apperception. Model of nation-building P.P. Skoropadsky was reduced to practical results in the course of nationalization of school education, unification of all types of primary school, liquidation of school management of the Holy Synod, compulsory primary education, centralization of education management. V.K. Vynnychenko in his own program outlined the main provisions of the national liberation struggle regarding state independence and autonomy.

Keywords: personality, personalized approach, problem of educational and pedagogical forecasting, national liberation struggles, educational reforms.

Постановка проблеми. Проблема персоніфікації освітньо-педагогічного прогнозування характеризуеться зростанням суперечностей, які посйлюються в сучасному глобалізованому світі. Йдеться про необхідність прогнозування зміни розвитку педагогічної освіти України та недостатне врахування світових тенденцій. Прогресивна педагогічна думка сьогодення диктуе життеву необхідність вивчення вітчизняного ретродосвіду освітньо-педагогічного прогнозування періоду національно-визвольних змагань українського народу 1917-1920 pр., який становить значну духовну та моральну цілісність.

Аналіз останніх досліджень і публікацій. До проблеми персоніфрікації освітнього процесу зверталися А.М. Алексюк, В.В. Нестеренко,
О.В. Попова, М.Б. Єсаулова та інші. Персоніфікований підхід до вивчення проблеми освітньопедагогічного прогнозування в Україні на початку XX століття досліджено нами в попередній публікації [14].

Виокремлення невирішених раніше частин загальної проблеми. Персоніфікований підхід до вивчення проблеми освітньо-педагогічного прогнозування в Україні періоду національновизвольних змагань 1917-1920 pр. не був предметом окремого дослідження та висвітлюеться нами у даній статті.

Мета статті - проаналізувати персоніфікований підхід до вивчення проблеми освітньопедагогічного прогнозування в Україні періоду 1917-1920 pp. 
Виклад основного матеріалу. У заявленому контексті особливий інтерес представляе просвітницько-педагогічна та громадсько-політична діяльність М.С. Грушевського, феномен якого детермінуеться низкою об'єктивних і суб'єктивних причин. По-перше, утвердження незалежності нашої країни вимагало обгрунтування ідейно-політичних засад новітнього державотворення. Наукова спадщина вченого, зокрема схема самостійного розвитку українського історичного процесу, численні праці 3 питань національно-визвольного руху, заслуги в конструюванні першої у XX столітті незалежної держави видавалися цілком придатними для формування базової української ідеї. По-друге, постать М.С. Грушевського імпонувала не тільки національно орієнтованому сегменту українського політикуму - він улаштовував i фрактично правлячу посткомуністичну еліту. Свідченням тому стала постанова Президії Верховної Ради України про відзначення восени 1991 p. 125-ліття від дня народження М.С. Грушевського. Наступні «круглі дати» також визначалися президентськими указами та урядовими постановами. По-трете, становлення в Україні інституту президентства вимагало опори на певну історичну традицію. Адже ані суто парламентська Українська Народна Республіка, ані гетьманат П.П. Скоропадського не вписувалися у схему нової державної конструкції. Тому так легко було реанімовано легенду про М.С. Грушевського - президента України. Вона набула поширення в публіцистичній, науковій літературі, серед політиків і владних структур. Саме такий чинник визначив потужну державну підтримку легітимації ціеї постаті. По-четверте, процес переосмислення нашого минулого, пошук адекватної потребам трансформації суспільства парадигми української історії відводив M.С. Грушевському роль головного репрезентанта національної історіографiї [11, с. 6].

За доби Центральної Ради діяч був вищою посадовою особою Української Народної Республіки, якщо й не харизматичним, та найавторитетнішим лідером українства. За досить влучним висловом М.М. Ковалевського, він виконував «верховну функцію репрезентанта держави». Можливо, саме це дало підстави A.I. Жуковському назвати М.C. Грушевського «першим некоронованим президентом української держави» [10, с. 180]. Історик і політик органічно поєднувалися в ньому, це поєднання додавало його постаті глибини, авторитетності, а разом з тим гнучкості, вміння йти на компроміси, коли цього вимагали інтереси справи, але при необхідності він міг продемонструвати силу духу, рішучість і навіть непоступливість [3, с. 7].

Вболіваючи за освітянську справу, історик закликав відкривати українські приватні гімназії. Він розумів, що заборона української мови затримуе розвиток культури, освіти, школи, призводить до денаціоналізації народу. Найбільше страждає україномовне сільське населення, яке змушене вчити своїх дітей нерідною мовою. Низка статей ученого порушували злободенні питання навчання у поширених в сільській місцевості початкових школах та інші питання освіти. Згодом вони вийшли друком у книжці «Про українську мову та українську школу» [1, с. 263].

3 іменем М.С. Грушевського пов'язані зародження, а відтак інституціоналізація української історіографрії як допоміжної дисципліни тоді, і спеціальної галузі історичної науки - сьогодні, роль та значення якої дедалі підвищуеться у сучасних умовах. Синтезуючи теоретичні погляди на історіографрію, слід, передусім, зазначити, що він розглядав її як складову історичної науки 3 допоміжними функціями, але не ототожнював предмет історії як науки і предмет історіографіï, не змішував їх із предметом джерелознавства, наголошуючи при цьому на цілісності історичного знання. Із ціеї цілісності вчений виводив і вибудовував свое бачення сутності предмета й завдань історіографії як сегмента історичної науки, що мае специфічні завдання та послуговуеться спеціальними методами, як процесу розвитку історичної думки, стрижнем котрого виступають історіеписання, його тенденщії [5, с. 5, 12-13].

Цікавим е бачення М.С. Грушевського щодо фонкціонування Академії наук. Учений виявився більш настійливим і публічним у сенсі обгрунтування свого бачення витоків академічної ідеї, стверджував, що ідеї української академії має власне, незалежне від російського академічного контексту коріння. Траєкторію руху української науки історик окреслював на ширшому, ніж російсько-імперське, - загальнослов'янському тлі. Аналізуючи академічну ідею на теренах України, вчений сягав думкою глибини віків, з'ясовував спадкові зв'язки в українській науці. У визначенні висхідного пункту академічної традиції в Україні, М.С. Грушевський стояв на позиції, так би мовити, «самозародження» української науки та її організаційних форм. Він був близький до тактики «блискучої ізоляції» українських досліджень та їх організаційних форм від інонаціональних впливів [4, с. 97].

Надзвичайно складною і малодослідженою e сырера духовного світу М.С. Грушевського. Один із фондаторів сучасної української біографістики В.С. Чишко вважав, що «історик ніколи не ризикуе аналізувати в науковому творі особливості внутрішнього світу та специфічні особливості психіки особистості». Адже ведуться праці в галузі психоісторії, вивчаються психологічні аспекти мотивації наукової творчості дослідників минулого [10, с. 183-184].

Якщо розглядати вплив інтелектуального середовища на методологію вченого, то слід зважити, що воно не мало ані дисциплінарних, ані географічних рамок, не обмежувалось ані Киевом, ані Львовом, ані Петербургом. Науковець формувався в европейському полі позитивізму, його теорії поступу й факторів розвитку, виявляв інтерес до концепцій ліберально-демократичного романтизму, особливо французького, німецького та польського, прихильники якого звертали увагу на народні традиції та самобутність націй [5, с. 8-9].

Подолання кризових явищ в українській історико-педагогічній науці, потреба в нових методологічних орієнтирах породили у середовищі фрахівців доволі гостру дискусію щодо теоретико-методологічної значущості творчої спадщини 
вченого. Ця полеміка загалом мало вплинула на усталену позитивну оцінку патріарха української історіографії. Але дала важливий імпульс подальшому критичному осмисленню його наукового доробку. Слід цілком погодитися з висновками Я.Й. Грицака: «Не можна не визнати величезних заслуг Грушевського в критичному перегляді старої парадигми в написанні історіі Східної Європи. Але, з іншого боку, не можна й не визнати, що парадигма, яку він запропонував, має досить обмежувальну дію: поза нею залишаються процеси й об'єкти, котрі теж заслуговують на увагу» [11, с. 7].

Вагомим 3 точки зору освітньо-прогнозувального потенціалу вважаємо доробок всесвітньовідомого вченого-натураліста, педагога і просвітителя B.I. Вернадського. Він був представником і водночас істориком російської науки, яка створювалася як державний проєкт i в такій же парадигмі розробив концепцію Української Академії наук. Учений трактував їі як територіальну наукову установу в Україні, як «продовження», або відгалуження Петербурзької (на той час Петроградської) Академії наук. Діяч пояснював, що організація нової Академії на Півдні Росії, тісно пов'язана з децентралізацією державного та економічного життя, а не 3 якимись формами самостійності України. Однозначність своєї позиції він підтверджував відмовою прийняти українське громадянство у 1918 р. У його світогляді поєднувалися патріотичні почуття до Росії, яку B.I. Вернадський бачив демократичною, оновленою, фредеративною, та України, яка все ж таки мала відстояти своє право на культурний розвиток та отримати національно-культурну автономію в межах Росії. Оновлена Росія, на думку вченого, позбавляла сенсу ідею державної самостійності України. Будучи тісно пов'язаним з Україною родинним походженням, однак світоглядно сформованим у атмосфрері російського академічного середовища, B.I. Вернадський схилявся до українськоросійського культурного дуалізму в Україні, що загалом було властиво певній частині інтелігенції, яка концентрувалася на той час у Києві. Він ратував за вільний розвиток і всебічну державну підтримку української мови і культури, з одного боку, а з іншого підносив значення російської культури для України. При розробці наукової політики учений не абстрагувався від національного аспекту [4, с. 90].

Говорячи про необхідність корінних змін у становищі народу, B.I. Вернадський поряд з такими радикальними заходами, як ліквідація самодержавства, розпуск постійної армії, розв'язання аграрного питання, налагодження загальнопотрібних робіт, п'ятим пунктом поставив освітню проблему: «Обов'язковість навчання у первинних школах і безплатність навчання у вищих і технічних (денних і вечірніх)». Таким чином, економічні (матеріальні) i духовні начала - це взаємозалежні атрибути народного життя, які слід розглядати у нерозривній єдності [6, с. 64-65].

Коло наукових інтересів B.I. Вернадського, кількість та значущість проблем, які він порушив у своїх працях, вражають і захоплюють. Учений започаткував, серед інших, нову на- укову галузь знань - біогеохімію, що поєднувала здобутки тогочасної геології, біології, хімії та фрізики. Він вивчав молекулярну та атомну структуру речовини, ініціював радіологічні дослідження, долучився до розвитку фрундаментального знання у галузі кристалографії, геохімії, радіогеології, мінералогії, грунтознавства, історії науки тощо. Світового визнання здобуло його вчення про ноосферу як сукупність живих організмів, де визначальну роль відіграє людський розум і людська діяльність. У 1918-1919 рр. учений брав активну участь у створенні Національної бібліотеки, системи національної вищої школи, зокрема й у заснуванні та розбудові Українського державного університету, Кам'янець-Подільського українського університету, Таврійського університету тощо. У питаннях освіти B.I. Вернадський послідовно відстоював принципи широкої автономії вищих навчальних закладів, демократичних засад їх управління та фрінансової підтримки з боку держави. Особливо вболівав за розвиток природничих наук в Україні. Він був головою Сільськогосподарського вченого комітету України, брав активну участь у підготовці Всеукраїнської наради природознавців, на якій 03 серпня 1918 р. виголосив доповідь «Об'єднання та організація природознавців України». А влітку 1920 р. заснував та очолив Комісію з вивчення природних виробничих сил у Криму [12, с. 6, 9].

Учений через розкриття своєї сутності у різні періоди життя всебічно проаналізував вузлові питання педагогічної антропології, переконливо висвітлив дію закону апперцепції. Засадничим у його поглядах на виховання було переконання, що сімейне і суспільне середовище повинно забезпечувати спроможність самореалізації людської особистості, повного вияв-

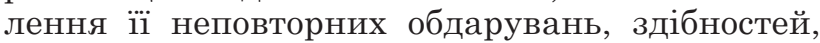
можливостей, тобто виконання нею глибоко індивідуальної життевої місії. B.I. Вернадський послідовно структурував таку синкретичну систему сімейного виховання, яка охоплювала раціональні, емоційні і підсвідомі чинники, тобто те, що одвічно лежало в основі синестетичного світосприймання наших предків. Стосовно виховних завдань сім'ї він орієнтувався на антропоцентризм, на пробудження інтересу дитини до встановлення їі власних етногенетичних коренів, усвідомлення сімейних традицій. Попередні покоління, предки, на думку B.I. Вернадського, акумулюють у собі великий інтелектуально-емоційний виховний потенціал, який має універсальне, загальнолюдське значення. Осягнення минувшини часто стимулюе самоствердження особистості, визначення нею світоглядних позицій. Широкомасштабна за своєю проблематикою і оригінальна за їі висвітленням спадщина вченого повинна зайняти належне їй місце в історії розвитку вітчизняної педагогічної думки [6, с. 266, 270].

Одним із найважливіших завдань освітньопедагогічного прогнозування є оцінка моделі національно-державного будівництва, на яку орієнтувався П.П. Скоропадський. Відзначимо, що українська суспільно-політична думка доби національно-визвольних змагань зароджувалася і викристалізовувалася у процесі збройної 
боротьби за самостійну українську державу. На відміну від національно-демократичної ідеології, яка розвивалася у фрарватері російського революційного руху і набула національних ознак у ході Лютневої революції, український монархізм формувався в умовах поразки українських національно-визвольних змагань. Серед політичного розмаїття української еміграції не припинялися пошуки лідерів, які могли б суттево вплинути на покращення політичної ситуації і консолідацію українського громадянства $[8$, с. 96$]$.

В українських політичних колах про генерала П.П. Скоропадського стало відомо лише у липні-серпні 1917 р., коли він долучився до українізації армії, ставши на чолі 1-го Українського корпусу, який у листопаді 1917 р. зупинив наступ на Київ більшовицьких військ. У жовтні 1917 р. генерал був обраний почесним військовим отаманом Вільного козацтва. Про чіткі політичні погляди П.П. Скоропадського на момент перевороту говорити немає підстав. Мова може йти лише про певні політичні настрої, які до того ж проявлялися в загальних рисах. Така невизначеність ставила у глухий кут навіть сучасників генерала 3 національного табору, які в залежності від ситуації оцінювали його то як українського патріота, то як зрадника. Усі погоджувалися, що П.П. Скоропадський був у соціально-економічних питаннях консерватором. Він очолював Українську народу громаду, що стала осердям сил, навколо яких фрормувалися противники Центральної Ради [13, с. 48].

Українська народна громада об'єднувала у своїх рядах монархічні кола населення України, мала досить привабливу, виразно національно забарвлену програму. Вчитаймося в їі основні положення: "Автократична або більшовищька форма правління недопустима... Кожний може виражати свої думки усно або письмово й має право поширювати їх 3 допомогою преси або іншим способом... Землю дістануть в першій мірі безземельні селяни й козаки, які своїми грудьми обороняли Україну перед зовнішніми й внутрішніми ворогами. ... Охорона інтересів робітників і їх державне страхування». Показовими були статті програми, які стосувались питань освіти: «В народній школі освіта ведеться українською мовою. В гімназії мову викладання визначають батьки більшістю голосів, а в університетах - продесорські колегії» [9, с. 94].

Маємо зауважити, що найбільше практичних результатів у період гетьманату П.П. Скоропадського виявлено в ході націоналізації шкільної освіти (відкриття українських шкіл; українізація діючих навчальних закладів; підготовка, видання і використання в освітньому процесі відповідних підручників, навчальних планів і програм, зокрема з українознавства; уведення штатної посади вчителя української мови та літератури, історії та географії України; підготовка вчителя для викладання українознавчих дисциплін). У напрямі створення єдиної системи освіти об'єднано всі типи початкової школи, ліквідовано органи керівництва школами відомства Святого Синоду, уведено обов'язкове початкове навчання. Проте, у зазначений період в освітньому просторі з'явилися негативні тен- денції: оновлення системи управління на основі централізації, реставрації імперської системи управління освітою (відновлення шкільних округ, ліквідація інституту комісарів, запровадження каральних санкцій проти вчительства, ігнорування громадської думки). Таким чином, в основу перетворень шкільної освіти були покладені такі основні принципи, як централізація, регламентація і українізація, що свідчить про суперечливість рефрорматорських процесів гетьманської доби [2, с. 150].

Ім'я видатного письменника, публіциста, суспільно-політичного діяча, революціонера В.К. Винниченка також відомо науково-педагогічній громадськості. Він був головою нового уряду Української Народної Республіки. У своїй програмі «Відродження нації» діяч виклав основні положення національно-визвольної боротьби: державна самостійність, незалежність, суто національний український уряд, українська мова в усіх установах, школах, активне національне визволення, незалежне військо, економічний союз і взаємодопомога. В.К. Винниченко не сприйняв національної партії. Тонкий психолог і спостережливий письменник, він вловлював настрої мас, робив узагальнення про безперспективність розвитку революції. Болісно відреагував на рецидиви командно-адміністративного управління, прояви бюрократизму, надмірної централізації влади [7, с. 192-193].

У період правління В.К. Винниченка Україна повертається до досвіду редрормування освітньої галузі часів Центральної Ради, а ідеї української педагогічної громадськості, розроблені нею педагогічні принципи стають підгрунтям шкільної рефрорми, яка поєднала в собі ініціативу «згори» - уряду та «знизу» - громадськості [2, с. 150-151].

Висновки та перспективи подальших досліджень. Отже, персоніфікований підхід до вивчення проблеми освітньо-педагогічного прогнозування в Україні періоду національновизвольних змагань означений тенденцією до багаторівневої педагогічної підготовки, а саме: М.C. Грушевський доклав зусиль до фрормування національної університетської освіти, дбав про розширення блоку українознавчих дисциплін; B.I. Вернадський розробив концепцію Української Академії наук, ставив питання про обов'язковість навчання у первинних школах і безоплатність вищої та технічної освіти, наголошував на важливості сімейного та суспільного середовища як фракторів спроможності самореалізації людської особистості; модель національно-державного будівництва П.П. Скоропадського зведено до практичних результатів у ході націоналізації шкільної освіти, об'єднанні всіх типів початкової школи, ліквідації керівництва школами відомства Святого Синоду, обов'язковості початкової освіти, централізації управління освітою; В.К. Винниченко у власній програмі виклав основні положення національно-визвольної боротьби щодо державної самостійності та незалежності.

В подальшому перспективним уважаємо вивчення персоніфікованого досвіду освітньо-педагогічного прогнозування періоду Української Радянської Соціалістичної Республіки. 


\section{Список літератури:}

1. Артемова Л. В. Історія педагогіки України : [Підручник]. Київ : Либідь, 2006. 419 с.

2. Березівська Л. Д. Реформування шкільної освіти в Україні у ХХ столітті : монографія. Київ : Богданова А. М., 2008. $406 \mathrm{c}$

3. Верстюк В. Ф. Михайло Грушевський - лідер та ідеолог Центральної Ради. Проблели вивчення історії Української революиї 1917-1921 рр. 2017. Вип. 12. С. 5-29.

4. Зайцева З. І.В.Вернадський і М. Грушевський: долання конфліктогенних зон в організації української науки. Україна ХХ століттл: культура, ідеологія, політика. 2013. Вип. 18. С. 89-100.

5. Калакура Я. С. Михайло Грушевський - фундатор історіографічних досліджень. Украӥнський історичний журнал. 2016. № 3. С. 4-17.

6. Лещенко А. В., Лещенко М. П. Володимир Вернадський і його просвітницько-педагогічна діяльність. Київ : Друкарня «Техсервіс», 2003. 292 с.

7. Мосіяшенко В. А., Задорожна Л. В., Курок О. І. Історія педагогіки України в особах : навчальний посібник. Суми : Університетська книга, 2020. 266 с.

8. Осташко Т. С. Павло Скоропадський - лідер українського гетьманського руху. Украӥнський історичний журнал. 2008. № 4. С. 96-110.

9. Пиріг Р. Я., Проданюк Ф. М. Павло Скоропадський: штрихи до політичного портрета. Украйнський історичний журнал. 1992. № 9. С. 91-105.

10. Пиріг Р. Я. Проблеми підготовки наукової біографії Михайла Грушевського. Украйнський історичний журнал. 2005. № 4. C. 178-189.

11. Пиріг Р. Я. Михайло Грушевський: суспільне усвідомлення історичної постаті. Украӥнський історичний журнал. 2016. № 4. С. 4-10.

12. Смолій В. А. Володимир Іванович Вернадський - вчений, організатор науки, політик, публіцист. Украйна ХХ століття: культура, ідеологія, політика. 2013. Вип. 18. С. 6-11.

13. Турченко Ф. Г. П. Скоропадський і М. Міхновський 1918 р.: дві моделі державного будівництва. Украӥнський історичний журнал. 2008. № 4. С. 48-59.

14. Черняк С. Г. Персоніфікований підхід до вивчення проблеми освітньо-педагогічного прогнозування в Україні на початку XX століття. International Journal of Innovative Technologies in Social Science. 2020. № 7(28). P. 21-26.

\section{References:}

1. Artemova L. V. (2006) Istoriya pedahohiky Ukrayiny: [Pidruchnyk] [History of pedagogy of Ukraine: [Textbook]. Kyiv: Lybid. (in Ukrainian)

2. Berezivs'ka L. D. (2008) Reformuvannya shkil'noyi osvity v Ukrayini u XX stolitti: monohrafiya [Reforming school education in Ukraine in the twentieth century: a monograph]. Kyiv: Bogdanova A. M. (in Ukrainian)

3. Verstyuk V. F. (2017) Mykhaylo Hrushevs'kyy - lider ta ideoloh Tsentral'noyi Rady [Mykhailo Hrushevsky is the leader and ideologue of the Central Rada]. Problems of studying the history of the Ukrainian revolution of 1917-1921, vol. 12 , pp. 5-29.

4. Zaytseva Z. I. (2013) V. Vernads'kyy i M. Hrushevs'kyy: dolannya konfliktohennykh zon v orhanizatsiyi ukrayins'koyi nauky [V. Vernadsky and M. Hrushevsky: overcoming conflict zones in the organization of Ukrainian science]. Ukraine of the twentieth century: culture, ideology, politics, vol. 18, pp. 89-100.

5. Kalakura Ya. S. (2016) Mykhaylo Hrushevs'kyy - fundator istoriohrafichnykh doslidzhen' [Mykhailo Hrushevsky is the founder of historiographical research]. Ukrainian Historical Journal, no. 3, pp. 4-17.

6. Leshchenko A. V., Leshchenko M. P. (2003) Volodymyr Vernads'kyy i yoho prosvitnyts'ko-pedahohichna diyal'nist' [Vladimir Vernadsky and his educational and pedagogical activities]. Kyiv: Drukarnya "Tekhservis". (in Ukrainian)

7. Mosiyashenko V. A., Zadorozhna L. V., Kurok O. I. (2020) Istoriya pedahohiky Ukrayiny v osobakh: navchal'nyy posibnyk [History of pedagogy of Ukraine in persons: a textbook]. Sumy: Universytet 's'ka knyha. (in Ukrainian)

8. Ostashko T. S. (2008) Pavlo Skoropads'kyy - lider ukrayins'koho het'mans'koho rukhu [Pavlo Skoropadsky is the leader of the Ukrainian hetman movement]. Ukrainian Historical Journal, no. 4, pp. 96-110.

9. Pyrih R. Ya., Prodanyuk F. M. (1992) Pavlo Skoropads'kyy: shtrykhy do politychnoho portreta [Pavlo Skoropadsky: touches to the political portrait]. Ukrainian Historical Journal, no. 9, pp. 91-105.

10. Pyrih R. Ya. (2005) Problemy pidhotovky naukovoyi biohrafiyi Mykhayla Hrushevs'koho [Problems of preparation of scientific biography of Mykhailo Hrushevsky]. Ukrainian Historical Journal, no. 4, pp. 178-189.

11. Pyrih R. Ya. (2016) Mykhaylo Hrushevskyy: suspilne usvidomlennya istorychnoyi postati [Mykhailo Hrushevsky: public awareness of a historical figure]. Ukrainian Historical Journal, no. 4, pp. 4-10.

12. Smoliy V. A. (2013) Volodymyr Ivanovych Vernads'kyy - vchenyy, orhanizator nauky, polityk, publitsyst [Volodymyr Ivanovych Vernadsky is a scientist, organizer of science, politician, and publicist]. Ukraine of the twentieth century: culture, ideology, politics, vol. 18, pp. 6-11.

13. Turchenko F. H. (2008) P. Skoropads'kyy i M. Mikhnovs'kyy 1918 r.: dvi modeli derzhavnoho budivnytstva [P. Skoropadsky and M. Mikhnovsky in 1918: two models of state building]. Ukrainian Historical Journal, no. 4, pp. $48-59$.

14. Cherniak S. H. (2020) Personifikovanyy pidkhid do vyvchennya problemy osvitn'o-pedahohichnoho prohnozuvannya v Ukrayini na pochatku XX stolittya [A personalized approach to the study of the problem of educational and pedagogical forecasting in Ukraine in the early twentieth century]. International Journal of Innovative Technologies in Social Science, no. 7(28), pp. 21-26. 